\section{BA Institute of \\ YK Business Administration \\ तर Karachi \\ Leadership and Ideas for Tomorrow}

Article 7

Volume 1 Issue 1 July - December 2006

7-1-2006

\title{
Corporate social responsibility
}

Akbar Abdul Ali

State Bank of Pakistan

Follow this and additional works at: https://ir.iba.edu.pk/businessreview

Part of the Place and Environment Commons

c) (i)

This work is licensed under a Creative Commons Attribution 4.0 International License.

\section{Recommended Citation}

Ali, A. A. (2006). Corporate social responsibility. Business Review, 1(1), 58-79. Retrieved from https://doi.org/10.54784/1990-6587.1095

This article is brought to you by iRepository for open access under the Creative Commons Attribution 4.0 License and is available at https://ir.iba.edu.pk/businessreview/vol1/iss1/7. For more information, please contact irepository@iba.edu.pk. 


\title{
ARTICLE
}

\section{Corporate Social Responsibility}

\author{
Akbar Abdul Ali
}

\begin{abstract}
This paper addresses fundamental questions of corporate governance that, why corporations need to accept responsibility for the social problems that plague our nation?

Discussion of corporate actions (i.e., mass layoffs, high CEO payoffs, discrimination in the work force) and how they are ultimately responsible for many of our social disorder (i.e., crime, suicide, alcoholism, domestic violence etc.). Article examines the corporate ethics and international business and how corporate law inhibits corporate social responsibility. I also discuss the philanthropic role of corporations to examine different perceptions of corporate ethics and its social responsibility which is generally lacking in Pakistan.
\end{abstract}

\section{EXECUTIVE SUMMARY}

WT hat is a corporation? While there are numerous definitions floating around, I think that a corporation most clearly can be defined as an invention of the state. That is, the state grants a corporate charter, upon request by an individual or group of individuals, which permits private financial resources to be used for public purposes. One of the main advantages to an individual "incorporating" his business is that in doing so he protects all of his personal assets and only that portion of the money that is invested in the corporation is at risk. In other words, creditors of the corporation cannot come after the individual's private home and money to secure payment for the corporation's debt. Sounds like a good deal, right? Well, during the early years, many believed the granting of corporate charters would assist in the expansion of the area in which the corporation existed. However, not everyone was in favor of granting corporate charters and viewed them as having the ability to attain great power and influence. In fact, one of the biggest victories for corporate power vests in the corporate law which stipulates that a corporation is an individual and, therefore, it is entitled to the same rights as a person. It was ruled that a private corporation is a natural person under the law, thereby entitling it to all the rights afforded to citizens of the country, including the right to free speech.

The ramifications of such a ruling are still felt today. By allowing the corporations these rights, we have effectively allowed them to influence government by lobbying legislators, use of the mass media, establish educational business schools, and donate money to political candidates. In essence, the corporations are allowed in all walks of government influence and have more power than an individual citizen who could never compete with the wealth and power of corporations. 


\section{What is Corporate Social Responsibility?}

Socially responsible businesses recognize that it makes good business sense to work in ways that demonstrate they care about the environment and the communities in which they operate. These organizations focus on the Triple Bottom Line. This is a measurement of business activity, which takes into account social, environmental and financial performance.

Now the question arises here that what are the benefits of socially responsible business practices? We live, work and trade in a global environment. This means that business operations have come under closer scrutiny by a growing number of technologically sophisticated and aware consumers who are increasingly concerned about their community, the environment and social justice. Large, successful corporations realize that a company's reputation is its key to business success. Information boom indicates that the socially responsible business practices have a positive impact on company's profits. Now finally the question which relates to corporate responsibility: What is Sustainability?

The past decade has witnessed a growing emergence of corporate reporting which has attempted to embody the sustainability concept. Sustainable development requires harmonizing the traditional focus of the financial bottom line with environmental and social aspects, with the underlying belief that the three spheres are interdependent and mutually enhancing. Corporations are adapting to 'sustainability' and developing new approaches to corporate reporting and accountability, recognizing the value of adopting the 'triple bottom line' approach.

Sustainability is defined as when your business delivers clothing, objects, food or services to the customer in a way that reduces consumption, energy, use, distribution costs, economic concentration, soil erosion, atmospheric pollution, and other forms of environmental damage. Sustainability adheres to the rule that "you should leave the world better than you found it, take no more than you need, try not to harm life or the environment, make amends if you do."

Aims of Ecological Sustainability: "redesigning organizations to contribute to sustainable economic development and the protection and renewal of the atmosphere." Aims of Human Sustainability: "building human capability and skills for sustainable, high level organizational performance and for community and societal well-being."

Emphasizing a company's economic goals does not mean forgetting social responsibility. Company should ensure people's health and safety, contribute to society, ecology, and human rights, be honest, be accountable, and actively consider stakeholders' needs (such as workers, consumers, investors, suppliers and local communities). It should pursue common interest with the stakeholders by making social responsibility part of its core mission. This can be described as "strategic philanthropic activity," and creates a Win-Win Business scenario in which both the company and the public benefit. 


\section{Ethics and Morality}

Ethics is the study of moral standards - the process of examining the moral standards of a person or society to determine whether these standards are reasonable or unreasonable in order to apply them to concrete situations and issues.

The ultimate aim of ethics is to develop moral standards that we feel are reasonable to hold - standards that we have thought about carefully and have decided are justified standards for us to accept and apply to the choices that fill our lives.

Morality is basically the standards that an individual or a group has about what is right and wrong, or good and evil.

Moral standards include the norms we have about the kinds of actions we believe are morally right and wrong as well as the values we place on the kinds of objects we believe are morally good and morally based.

Ethics is the discipline that examines one's moral standards or the standards of a society. It asks how these standards apply to our lives and whether these standards are reasonable or not. That is, whether they are supported by good reasons or poor ones. A person starts to do ethics when he or she takes the moral standards absorbed from family, religion, and friends and asks: What do these standards imply for the situations in which I find myself? Why should I continue to believe in them? What can be said in their favor and what can be said against them? Are they really reasonable for me to hold? Are their implications in this or that particular situation reasonable?

\section{CORPORATE SOCIAL RESPONSIBILITY}

\section{The Issue}

What is the extent of a corporation's social responsibility?

Milton Friedman said that the "One and only one social responsibility of business [is] to increase profits so long as it stays within the rules of the game, which is to say, engages in open and free competition without deception or fraud."

In recent times, some people have come up with new ideas of corporate social responsibility. Sections of annual corporate reports are dedicated to social responsibility, universities have skillful chairs of corporate responsibility and mutual funds containing only "socially responsible" companies have been created, even though they consistently underperform. What then is required to be a good corporate citizen? 


\section{CORPORATE ETHICS AND INTERNATIONAL BUSINESS: SOME BASIC ISSUES}

\section{Introduction}

Questions on ethical justification of human activity have occupied philosophers since ancient times. Whether Lao-tsu, Confucious, the writers of the good book, ethical thinkers: they all have comparable concepts of what is good and bad human behavior and what constitutes sensible human existence. Those of us wishing to discover suitable working principles can refer to Immanuel Kant, Max Weber, or Hans Jonas. One way or the other, no one today can claim that there are no interesting impulses for appropriate ethical reflection. However, anyone who examines the current social and environmental situation in the world is liable to disappointment on moral-philosophical practices.

Since the mid-seventies and increasingly since the beginning of the nineties, the ethical perspective has been moving more and more to the forefront of social thought. Every significant profession and every institution that thinks anything of itself has its "something ethics" to proclaim - environmental ethics, media ethics, research ethics, and even corporate ethics are the consequence. The latter has recently, along with environmental ethics, gained most in significance. There are now a great number of national and international books, seminars, symposia, professorships, ethics networks, and journals exclusively devoted to business ethics.

Why should this be so? Has there been a fundamental shift in social value systems and has the worth of ethical argument increased as a result? That would be an explanation, for when traditional ways of life and institutions are no longer taken for granted, philosophical ethics, guided by the idea of sensible human life, seeks generally valid arguments about good and just behavior in a methodical way. There is no need to point out that we are living in a time of great social change. If social change were to move in the direction of higher morals, then all social groups and institutions including business enterprises - would be faced with new legitimation demands. Economic performance alone is no longer enough to give businesses legitimacy. Noneconomic demands, e.g., the sustainable fulfillment of social and environmental responsibility in industrialized and developing countries, have been increasing their significance for legitimation for many years.

Or does the new interest in ethical debate stem from a publicly perceived violation of old "unspoken grounds for legitimation"? Is ethical thought so passionately in demand because existing morals are in such dire circumstances? There is at least the suspicion that those who talk a lot about ethics may be on a rather shaky moral footing themselves and are using ethical plausible excuses to soften a critical public. Looking over what has passed for "market economy" in many Eastern European countries following the demise of communism, one almost finds oneself agreeing with this argument. 
Philosophical reflection is without doubt a fulfilling and intellectually challenging matter - also for those that bear responsibility in corporations. But if one wishes to do more than just get traditional moral philosophical knowledge over to people or preach romantic idealism, then ethics, including corporate ethics, must come down from its realm of "ideas" or "values" and establish itself in day-to-day reality. Acting responsibly would then not mean swearing faithfulness to higher notions of approvable behavior, but would emerge from a very worldly setting in which a corporation or individual's activity has to be justified in the light of different values in most societies. Such a debate will have to be based on real people with all their strengths and weakness, not on ideal people that we would all like to have but seldom meet.

Acting responsibly always and primarily means acting intelligently, i.e. carefully weighing up the benefits and harm that one's own actions can bring. All moral activity occurs on the basis of a balance between the realization of interests and the avoidance of physical, social, or even state sanctions. Here I share the view of the German philosopher and business consultant Rupert Lay "that people - privately, in corporations or other institutions - usually tend to act according to the principle of "marginal ethics". In other words, they are prepared (consciously or unconsciously) to pay a mental, social, emotional, and financial price only in so far as they can expect a marginally higher mental, social, emotional, and financial return at least in the long-term. An institution's efforts to go beyond the level of marginal ethics lead to a higher common good, and that, in the final analysis, this again has positive effects for the institutions concerned."

From this perspective, much of what is called "unethical conduct" is primarily unintelligent, occasionally even stupid behavior that focuses on supposed short-term advantages without considering mid- and long-term benefits. The inability of ethics is shown in the fact that most people choose to maximize their own benefits when economic and political decisions have to be made, and are only prevented from acting against the common interest by governments branching out into many walks of life. Intelligent action is acting in one's enlightened self-interest and thus compatible with the selfish tendencies in our societies. To assume that altruism and a holistic worldview are predominant human characteristics would be unrealistic.

There are two reasons that make it worthwhile to reflect on business ethics. One is that social change in the direction of a higher social and moral prescription is not only urgently necessary but also possible. The other is that moral enthusiasts who run the risk of originating when faced by institutional resistance are - at least in my view the more attractive and lesser evil than thoughtless administrators of today. As per Hannah Arendt, who spoke of the "banality of evil" during the Eichmann trial in Jerusalem: I agree that "not demoniac evil, not unconscious hatred, biting rivalry, or destructive greed were the motives of the mass murderer - no, there were no deeper motives at all - just thoughtlessness, a failure to think, and dull observance of routine behavioral rules." 
So as not to be misunderstood - I am not comparing those in responsible positions in corporations and authorities with a mass murderer. But if there is a lack of thought in situations deciding the life and death of millions of people, how much more feasible is it in situations which are not of such vital significance? I presume that also today, the analysis of a situation in which an individual's action turned out to be "evil" will probably more often point to thoughtlessness, taking things for granted that should not be taken for granted at all, to self-justifications and clichés, than to circumstances where someone who really knew better was acting in an evil and destructive way.

\section{THE PERCEPTION OF CORPORATE ETHICS}

\section{Society's Perception}

If one consults the Holy Scriptures for the answer to the question of whether profitoriented activity is compatible with behavior pleasing to God, then one will find little comfort in preaching, for instance, "A merchant shall hardly keep himself from doing wrong; and bargain shall not be freed from sin. Many have sinned for small matters." Even more modern commentaries on the compatibility of profit and morals are rather skeptical. It is said that the Austrian social critic Karl Kraus, in answer to a question from a student as to how one could study business ethics, declared that one could not, one had to decide on one or the other.

As regards the social acceptance of corporate ethics, too, matters look rather bad; in the last 10 to 15 years, society's image of private industry, and particularly of large corporations, has become shaped by skeptical unease. Many believe that a corporation cannot simultaneously have high principles and high profits. In fact, there is an increasingly common view that many corporations are ethically irresponsible, pursuing their profits unscrupulously at the cost of the environment and the safety and health of consumers.(1)

Another survey in 1990 focusing on business students brings little cheer either. In answer to the question "How ruthless are you prepared to be to get to the top of your chosen career?", $2 \%$ answered "extremely ruthless", 14\% "very ruthless", and 39\% "moderately ruthless". The same MBA students had a more than skeptical opinion of the moral state of the modern business world: $5 \%$ thought it had no morals at all, and $35 \%$ thought it had "very few" morals.

\section{Executives' Self-Perception}

But evident problems emerge when management circles themselves are asked directly. In 1977, Brenner and Molander published a study (3) where 43\% of the executives interviewed felt compelled to resort to practices they considered shady, but apparently found necessary for the survival of their companies and hence their own careers. One of the reasons underlying the sad state of affairs in this study was a performance appraisal system that concentrated almost exclusively on short-term financial results 
criteria. Furthermore, Brenner and Molander report that most of the incentive schemes in operation primarily rewarded short-term cost-cutting, sales-boosting, profit-raising action irrespective of its long-term social and therefore also economic effects.

Various more recent studies of executives' moral perceptions of themselves confirm the existence of conflicts. (4) Executives often feel their decisions to be a choice between commercial necessity within the time limits of the profit and loss account and the demands of their conscience. A study by the Institute for Applied Marketing Science, (IFAM) revealed an interesting distinction: lower level executives or middle management often seem to feel more under pressure and to experience greater moral difficulties than upper level executives, who showed great interest in ethical questions.

An attitude familiar from the psychology of repression and projection is interesting in this connection: problems tend to be seen as having external causes (e.g., low moral standards in society), but positive solutions are sought internally, here from executives.(5)

\section{Corporate Ethics as a Matter of Leadership}

Presumably, no one would argue that there should be an "either/or" relationship between ethical corporate conduct and the pursuit of profit. The words of former Federal Chancellor of Germany, Helmut Schmidt, had to say from a politician's point of view is also of great significance for executives: "We must all ask ourselves how we get from the state we are to the state we ought to be. Whoever tries to answer this question by proposing the shortest possible route from a purely ethical point of view runs a high risk of ending in practical catastrophe. Or, the other way round, whoever attempts the shortest possible route from a purely practical point of view can end in ethical disaster."

How can a business enterprise respond successfully to the day-to-day challenge of corporate ethics? In my view, with various instruments on three levels: firstly, "common sense" or "moral reason", secondly "corporate codes of conduct", and thirdly, "comprehensive personnel policies and holistic management development".

\section{Moral Common Sense}

The following rules of thumb, referred to as moral common sense, are significant here (6)

(a) Avoid harming others (b) Respect the rights of others (c) Do not lie or cheat

(d) Keep promises and contracts (e) Obey the law (f) Prevent harm to others

(g) Help those in need (h) Be fair (i) Reinforce these imperatives in others.

In order to be able to represent a point of view on a fairly firm footing, all the relevant facts have to be collected and illuminated and evaluated from different angles. This needs discussions on a broad basis to take account of all the pluralistic opinions and interests that there are. In view of the urgency and the complexity of many of today's 
problems, thinking in old terms of right/left categories is no longer of much help. Ideological lines of demarcation or fundamentalist rejections do not improve the quality of solutions, on the contrary: prejudice acts like a wall, preventing our awareness of certain things.

If conflicting opinions (acceptable in form but hard in content) are considered a narcissistic offence in a company, then that company lacks more than just an opposition culture and ability to cope with conflict. Openness to pluralistic opinions is one of the essential conditions for the most comprehensive perception possible of reality. Especially for the social acceptance of industrial behavior, whose complexity and benefit-risk ratio is not easy for the lay public to grasp, the search for consensus in dialogue is vital for survival. A corporation that is not prepared to talk runs the risk of soon having no more to say.

Decision-making processes are difficult when they involve informed opinion outside the company that wishes to include its concerns and interests in solutions, but has other criteria than the economic and bases its judgement on other value systems. (7) On the one hand, dialogues are "open processes", i.e., it cannot be planned how they will develop and the effects and consequences are visible only to a limited extent. On the other, dialogues do not automatically lead to agreement, and run the risk then of overflowing endlessly and getting involved in controversies that are less and less relevant instead of working out an acceptable practical compromise for both sides. Dialogues are particularly vulnerable if one or the other side sets itself up as morally superior or butts into other worlds normatively without sufficient expert knowledge.

Nevertheless, controversies must be argued out. Although the final decision on corporate policy lies within the corporation itself and cannot be transferred outside, the harmonization of controversial views is more sustainable through discussion than through power. All those involved must refrain from claiming superiority, think over their own positions, and if necessary revise them. Openness and pluralism are required, though not arbitrariness or cheap "tolerance" to avoid arguments. True dialogue, in this case, differs from manipulative persuasion and modern advertising by dealing critically both with the necessity of acting in an economically reasonable manner and with wider public interests.

Dialogue with various social groups and being prepared to listen to the opinions of people from a completely different world of thought who base their concepts of ethics on other systems of values can improve the quality of all types of solutions, not only those of corporate codes of conduct. Socrates' distinction between truth and certainty still has great meaning today: people can be very sure of their opinions and consider this subjective certainty to be the objective "truth". The views of others who do not share this certainty are not "untrue" or "mistaken" - rather, one certainty is opposed to another. 


\section{Personnel Policy and Management Development}

At the beginning of this century, Max Weber, the eminent German sociologist, pointed out the particular responsibilities of leaders with the following words: "People who must make political or economic decisions on matters that affect other people's lives will, unless they have lost all reason, find themselves forced more and more to evaluate not only their ethical motivations, but also their decisions' likely consequences based on their knowledge and conscience." In a political context, Henry Kissinger pointed out that practical politics is always in danger of being overtaken by events and becoming thoroughly unprincipled, and declared that it was very difficult to carry out practical politics successfully without strong moral conviction. The same applies to managers in businesses and other institutions.

If we are convinced that profit, sales, or other commercial successes can never be ends in themselves but are only legitimate if they serve people and society, then the criteria for personnel recruitment and the content of management development should be extended idealistically. Yet another problem area has to be addressed: do institutions like corporations (or trade unions, parties, etc.) allow the people who work in them sufficient responsibility of their own? Or do they limit the development of their people, including their moral development, in an illegitimate way?

\section{Good Ethics are Good Business}

Why should a company consider ethics in directing its behavior - on top of law, selfinterest, and convention? The worst conceivable result of high moral standards would be competitive or other tangible loss because the special efforts and costs a company attaches to ethical consideration result in net disadvantages for it. There are a number of indications that the short-term profit from ethical conduct does not exactly burst into the limelight or even show clearly measurable financial disadvantage. It would be dishonest to exclude these effects as an option in action on corporate ethics.

On the other hand, there are many empirical examples in which unethical corporate behavior caused a great social outcry and intervention from the authorities, and presented no favorable options even in the short-term. In these cases it is easy to show that unethical conduct can be a burden on a corporation and that high ethical standards can be seen as an asset.

A second conceivable possibility is that financial disadvantages due to investments over and above those required by law (for instance in environmental, social, or safety areas) or withdrawing from sale for ethical reasons could be compensated and balanced out by non-financial advantages (e.g., the company's reputation). The problem here is that investments and falling sales are easier to measure than increased opportunities from an enhanced reputation. 
At least for enlightened corporations, commercial success now means more than just how big the year's profit is. Profits to companies are like food to people: an absolute necessity, without which they die. But only a few - sick - people would consider eating to be the central or only purpose of life. The reputation of a company is one of its most valuable assets, even if it does not appear directly in the balance sheet (that's why most accounting bodies therefore suggest that "goodwill" should become a balancesheet item). The verdict of the public depends significantly on the company's perceived contribution to socially valued ends. Meeting customer requirements in the extended sense, i.e., acting in a socially and environmentally responsible way and using energy and non-renewable resources wisely, are important blocks in the mosaic of commercial success.

A third possibility is that ethical dealing might be worthwhile from both the financial and non-financial points of view. I personally tend to see this as the most likely possibility, at least in the mid- and long-term, for the following reasons:

\section{Reduction in the cost of friction with the social environment}

First and foremost, ethical conduct brings reductions in the cost of friction with the social environment (for private individuals and institutions). For corporations, social friction costs arise where behavior which is legal but seen as illegitimate or unethical leads to calls for boycotts from religious or other social organizations. Whether a critically committed public demonstrates in front of the works gates, charitable organizations set up wailing walls, or the media "put on pressure" through critical reporting-for the corporation concerned, this means loss in social recognition. Whether this leads to a fall in the share price or physically measurable sales losses occur or not are of secondary importance. Criticism "from outside" generally means that management capacity is taken up with defensive activity and is therefore not free for the shaping of the future. Intelligent corporations forbid dealings that could provoke negative social reactions.

On the other hand, there is growing evidence that a corporation's "image" can become a competitive advantage because a "positive coefficient" arises. This can become a decisive market advantage where a corporation offers products and services that are comparable in quality and usefulness with those of other companies. In the USA, there are a number of indications that so-called "green consumers" represent an increasingly important niche in various sales markets, and companies that are environmentally exemplary and go beyond the minimum legal requirements can gain market advantages.

\section{Employees' Motivation}

Other costs can arise through friction with one's own employees. The fact that a company is the focus of public criticism (but also in a situation where employees see that colleagues are promoting their careers in an unethical way) can have disastrous results for morale and job satisfaction in a corporation. In the mid- and long-term, this 
can lead to valuable employees looking for other work and leaving the corporation. As employees are a corporation's most valuable "capital", this alone is reason enough why unethical conduct cannot lie in a corporation's interests.

Various empirical studies reveal a positive correlation between ethical conduct in a corporation and job satisfaction. Where top management is seen as giving strong support for ethical conduct, job satisfaction increases together with the degree of employee identification with the corporation. Everything points to the conclusion that a positive reciprocal relationship exists between "job satisfaction" and "ethical conduct". Applied business ethics become a component of "corporate identity", the totality of value systems, thought and decision patterns, modes of behavior, and structures within a corporation that transmits a positive "us-feeling" to employees and thus boost motivation to work.

The fact that corporate behavior which is at least frictionless but wherever possible goes beyond marginal ethics also prompts customers to buy and motivates serious investors to purchase shares, and that the direct neighbors (residents, communities) look to the corporation with pleasure and pride reinforces employees' positive identification. What formulated for individuals also applies to whole corporations: they are not just what they are, but also what they have set themselves as ideals. Even if they do not emulate these one hundred per cent, a part of their being is marked by the mere fact of wanting to.

There are a number of indications that corporations whose ethical conduct is considered above blame are seen as more attractive employers than those which have been publicly criticized due to failure to recognize their responsibilities or even due to willful damage to the welfare of the community or the environment. A poll of business studies students carried out in 1990 by the Basel company Prognos AG revealed that $88 \%$ regard "work satisfaction", 67\% a "good working atmosphere", and 66\% a "job that makes sense" as an important criterion in choosing an employer. These are all factors, which can hardly be true of companies where Greenpeace demonstrates in front of the factory gates to call for a boycott.

Corporations are now no longer measured on what they produce, but on what they present. The strength of such trends can of course change again, especially when the labor market develops unfavorably for those seeking employment. But an increasing number of citizens, whether as employees or consumers, are taking ethical viewpoints seriously - more seriously than 10 or 20 years ago.

\section{Protection of Commercial Freedom}

Many of those with responsibility in corporations are complaining about an increasing and already too dense jungle of laws, stipulations, and directives. Commercial freedom, the complaint goes on, can no longer exist within the ever-narrower straitjacket of state regulations - too many rules endanger the industrial success. There is a good deal 
of evidence that such complaints have a grounding in reality in many respects, and that "less state" can have a promising effect on corporate commitment.

Freedom is, however, always freedom as ethical duty and may thus be demanded only as a correlate of responsibility. Anyone who wishes to help avoid further regimentation of the economy and correct inappropriate legal developments must offer plausible proof of ethically responsible conduct.

Ethically responsible corporate dealings mean dealings beyond the status quo, active shaping and forward-looking ethical equilibrium. Whoever maintains a running battle on the basis of current law to defend positions that might have been based on a consensus many years ago but which are now regarded as illegitimate and will be even more so in the future, is not being business like but negligent. Such companies support those social forces that demand more controls, narrower legislative chains, and thus more state bureaucracy.

\section{Business Ethics as Comprehensive Competitive Advantage}

Innovation, efficiency, effectiveness, the ability to utilize market potential optimally, recognize the signs of the times, and the art of saving costs and expense in the right place at the right time will continue to be of greatest importance alongside all the other corporate virtues. However, an additional element will gain in significance: applied business ethics. It will become more and more a new, solid basis for competitive ability, breaching the limits of classical markets. The more affluent a society is, the more significant non-material values become. Corporations that act in a visibly ethical way will be preferred by informed consumers more and more. This fact will become a problem for those corporations that ignore moral aspects, and for others it will be an opportunity to get to the very top.

\section{How Corporate Law inhibits Social Responsibility}

It is disturbing to realize that the many social ills created by corporations stem directly from corporate law. It dawned on us that the law, in its current form, actually inhibits executives and corporations from being socially responsible. Making people aware of this problem we must build consensus to change the law so it encourages good corporate citizenship, rather than inhibiting it.

The provision in the law I am talking about is the one that says the purpose of the corporation is simply to make money for shareholders. Every jurisdiction where corporations operate has its own law of corporate governance. But remarkably, the corporate design contained in hundreds of corporate laws throughout the world is nearly identical. That design creates a governing body to manage the corporation - usually a board of directors - and dictates the duties of those directors. In short, the law creates corporate purpose. That purpose is to operate in the interests of shareholders. The typical duty of directors in some Section of the Business Corporation act, which reads: 
.....the directors and officers of a corporation shall exercise their powers and discharge their duties with a view to the interests of the corporation and of the shareholders......

Although the wording of this provision differs from jurisdiction to jurisdiction, its legal effect does not. This provision is the motive behind all corporate actions everywhere in the world. Distilled to its essence, it says that the people who run corporations have a legal duty to shareholders, and that duty is to make money. Failing this duty can leave directors and officers open to being sued by shareholders.

These sections dedicates the corporation to the pursuit of its own self-interest (and equates corporate self-interest with shareholder self-interest). No mention is made of responsibility to the public interest. These sections and their counterparts explain two things. First, they explain why corporations find social issues like human rights irrelevant - because they fall outside the corporation's legal mandate. Second, these provisions explain why executives behave differently than they might as individual citizens, because the law says their only obligation in business is to make money.

This design has the unfortunate side effect of largely eliminating personal responsibility. Because corporate law generally regulates corporations but not executives, it leads executives to become inattentive to justice. They demand their subordinates "make the numbers," and pay little attention to how they do so. Directors and officers know their jobs, salaries, bonuses, and stock options depend on delivering profits for shareholders.

Companies believe their duty to the public interest consists of complying with the law. Obeying the law is simply a cost. Since it interferes with making money, it must be minimized - using devices like lobbying, legal hairsplitting, and jurisdiction shopping. Directors and officers give little thought to the fact that these activities may damage the public interest.

Lower-level employees know their livelihoods depend upon satisfying superiors' demands to make money. They have no incentive to offer ideas that would advance the public interest unless they increase profits. Projects that would serve the public interest - but at a financial cost to the corporation - are considered naive.

Corporate law thus casts ethical and social concerns as irrelevant, or as stumbling blocks to the corporation's fundamental mandate. That's the effect the law has inside the corporation. Outside the corporation the effect is more devastating. It is the law that leads corporations to actively disregard harm to all interests other than those of shareholders. When toxic chemicals are spilled, forests destroyed, employees left in poverty, or communities devastated through plant shutdowns, corporations view these as unimportant side effects outside their area of concern. But when the company's stock price dips, that's a disaster. The reason is that, in our legal framework, a low stock price leaves a company vulnerable to takeover or means the CEO's job could be at risk. 
In the end, the natural result is that corporate bottom line goes up, and the state of the public good goes down. This is called privatizing the gain and externalizing the cost.

This system design helps explain why the war against corporate abuse is being lost, despite decades of effort by thousands of organizations. Until now, tactics used to confront corporations have focused on where and how much companies should be allowed to damage the public interest, rather than eliminating the reason they do it. When public interest groups protest a new power plant, or mercury poisoning, the groups don't examine the corporations' motives. They only seek to limit where damage is created (not in our back yard) and how much damage is created (a little less, please).

But the where-and-how-much approach is reactive, not proactive. Even when corporations are defeated in particular battles, they go on the next day, in other ways and other places, to pursue their own private interests at the expense of the public.

I believe the battle against corporate abuse should be conducted in a more holistic way. We must inquire why corporations behave as they do, and look for a way to change these underlying motives. Once we have arrived at a viable systematic solution, we should then dictate the terms of engagement to corporations, not let them dictate terms to us.

We must remember that corporations were invented to serve mankind. Mankind was not invented to serve corporations. Corporations in many ways have the rights of citizens, and those rights should be balanced by obligations to the public.

Many activists cast the fundamental issue as one of "corporate greed", but that's off the mark. Corporations are incapable of a human emotion like greed. They are artificial beings created by law. The real question is why corporations behave as if they are greedy. The answer is the design of corporate law.

We can change that design. We can make corporations more responsible to the public good by amending the law that says the pursuit of profit takes precedence over the public interest. I believe this can best be achieved by changing corporate law to make directors personally responsible for harms done.

Let me give an example of how directors' responsibility works in the current system. Under Companies \& SECP Laws, directors are held personally liable for false and misleading statements made in prospectuses used to sell securities. If a corporate prospectus contains a material falsehood and investors suffer damage as a result, investors can sue each director personally to recover the damage. Believe me, this provision grabs the attention of company directors. They spend hours reviewing drafts of a prospectus to ensure it complies with the law. Similarly, everyone who works on the prospectus knows that directors' personal wealth is at stake, so they too take great care with accuracy. 
That's an example of how corporate behavior changes when directors are held personally responsible. Everyone in the corporation improves their game to meet the challenge. Since the potential penalties are so severe, directors are on the side of caution. While this has not eliminated securities fraud, it has over the years reduced it to an insignificant percentage of the total capital raised.

I propose that corporate law be changed in a similar manner - to make individuals responsible for seeing that the pursuit of profit does not damage the public interest. To pave the way for such a change, we must challenge the myth that making profits and protecting the public interest are mutually exclusive goals. The same was once said about profits and product quality, like before Japanese manufacturers taught USA otherwise. If we force companies to respect the public interest while they make money, business people will figure out how to do both.

The specific change I suggest is simple: add 26 words to corporate law and thus create what I call the "Code for Corporate Citizenship". This would mean amending some section to add the following clause. Directors and officers would still have a duty to make money for shareholders,

......but not at the expense of the environment, human rights, the public safety, the communities in which the corporation operates or the dignity of its employees.

This simple amendment would effect a dramatic change in the underlying mechanism that drives corporate wrongdoing. It would make individuals responsible for the damage companies cause to the public interest, and would be enforced much the same way as securities laws are now. Negligent failure to abide by the code would result in the corporation, its directors, and its officers being liable for the full amount of the damage they cause. In addition to civil liability, the courts would have the right to criminally prosecute intentional acts. Injunctive relief - which stops specific behaviors while the legal process proceeds - would also be available.

Compliance would be in the self-interest of both individuals and the company. No one wants to see personal assets subjected to a lawsuit. Such a prospect would surely temper corporate managers' willingness to make money at the expense of the public interest. Similarly, investors tend to shy away from companies with contingent liabilities, so companies that severely or repeatedly violate the Code for Corporate Citizenship might see their stock price fall or their access to capital dry up.

Many would say such a code could never be enacted. But they're mistaken. I take heart from a 2000 Business Week/Harris Poll that asked people which of the following two propositions they support more strongly:

- Corporations should have only one purpose - to make the most profit for their shareholders - and pursuit of that goal will be best for people in the long run. 
- $\quad$ Corporations should have more than one purpose. They also owe something to their workers and the communities in which they operate, and they should sometimes sacrifice some profit for the sake of making things better for their workers and communities.

An overwhelming 95 percent of people chose the second proposition. Clearly, this finding tells us that our fate is not sealed. When 95 percent of the public supports a proposition, enacting that proposition into law should not be impossible.

If business people resist the notion of legal change, we can remind them that corporations exist only because laws allow them to exist. Without these laws, owners would be fully responsible for debts incurred and damages caused by their businesses. Because the public creates the law, corporations owe their existence as much to the public as they do to shareholders. They should have obligations to both. It simply makes no sense that society's most powerful citizens have no concern for the public good.

It also makes no sense to endlessly chase after individual instances of corporate wrongdoing, when that wrongdoing is a natural result of the system design. Corporations abuse the public interest because the law tells them their only legal duty is to maximize profits for shareholders. Until we change the law of corporate governance, the problem of corporate abuse can never fully be solved.

\section{Balancing Bottom Line Concerns with Social Responsibility}

Social responsibility must be inherent in an organizations' objective strategy, simply to aid the well being of society. However, without bottom line concerns, social responsibility cannot be implemented. In most cases, a company or organism must make a profit before it can contribute to a society in dyer need. Hence, when the business entity is profiting, social integrity can be regarded as preeminent concern.

For example, the Vermont ice cream giants Ben \& Jerrys, who pride themselves on philanthropy, donates 7.5 percent of their profits to charity. If more organizations engaged in this activity, society would be more equal, hence, more stable. However, without overhead being met, the super premium ice cream gurus wouldn't have a chance with secondary concerns such as monetary philanthropy.

According to Levi Strauss, Chairman and Chief Executive Robert Haas: "The organization needs to be an ethical creature - an organism capable of both reaping profits and making the world a better place to live."

The profits exist, hence in theory, Levi's can afford the practice of ethical concerns. For example, they do not conduct business with those who violate their stringent standards of work environment and ethics. The conglomerate pulled an astounding $\$ 40$ million worth of business out of a vast Chinese market. This act was in protest of human rights violations. 
The laborious task of balancing bottom line concerns with social responsibility demands careful analysis. The firm concern of public relations and ethical integrity weighs substantially in the planning for a companies continued success.

\section{Wise Management or Public Relations Strategy?}

The weight of Public Relations is tremendous. When a company performs philanthropy, people are impressed. This contributes to overall image, thus, sales of products and/or services can only increase.

For example, The Calvert Group, a mutual fund company, demonstrated social zeal in prohibiting investments in companies that produce guns, cigarettes and vodka. Hence, an angelic image was produced. This in turn increased overall business with other entities that appreciate what the mutual fund company did.

When the Body Shop decided to use simple, natural ingredients harvested without harm to the environment, and for the benefit of indigenous people, business escalated. Hence, the image of third world sensibility proved advantageous.

The concept of public relations seems to weigh higher than all things considered regarding the implementation of performing that which is utilitarian, or, the greatest good for the greatest number. For example, a company contributing money to clean harbors or to make drinking water healthier would certainly publicly announce the respective endeavor.

Societal improvement is drastically needed. Hence, it is imminent that corporations make a serious effort to incorporate this. However, there must be a pay back for the company or the philanthropy is not feasible. Ideally, there are ways that companies can contribute to society and be rewarded simultaneously. Theoretically, through corporate philanthropy, everyone is happy and quality of life increases.

\section{Personal Philosophy}

Today, it appears as if there are more problems on a macro scale than ever before. Therefore, social responsibility by organizational entities is more important than ever. Governments are relied upon to allocate tax money to the well being of society. For example, lifestyles of the mentally ill and homeless could be improved. Also, the world's environmental conflict is currently exponential. This includes the extinction of flora and fauna.

Perhaps there is absolutely no way the government can do enough. Hence, organizations need to contribute. However, in doing this, the very important issue of public relations is improved. In addition, the company gains enormous tax benefits.

I still believe that more incentives are needed for corporations to help improve the future holistic entity of the earth. The overall issues at stake are the environment, and the human quality of life now, and in future generations. 
Perhaps the greatest incentive to participate in social good is social good itself. People and organizations need to be aware of problems. This constitutes public relations campaigns by the government, profitable companies and even the non-profit sector. Although steps are currently being taken to improve life on earth, greater measures must be implemented in order for our species to increase its quality of life, rather than diminishing it.

\section{RECOMMENDATIONS}

\section{Corporate codes of conduct for sensitive matters}

Not everything that is legal is legitimate. An internationally active corporation, which has to function in different legal and social frameworks and which strives for uniform ethical standards, is well advised to develop codes of conduct for its sensitive activities. There is no prior harmony between corporate or individual profit and what is to be preferred from a social point of view. Indeed, there is a whole set of potential conflicts that a corporation needs to think about how to minimize.

Corporate codes of conduct are defined here as standards of behavior, which a corporation adopts without being compelled to by law, but which then become binding on all employees, in order to minimize potential conflicts arising from undesirable effects of normal business activity on society and environment. Such corporate codes of conduct make it clear that the management of the corporation is not indifferent to how business goals are achieved.

As a kind of negative ethics at least, corporate codes of conduct rule out what the corporation believes to be clearly unacceptable behavior. As Wilhelm Busch said, "All the good beneath the sun is always bad you haven't done."

Of some importance here is the question of whether one should almost imperialistically enforce one's own standards in cases of doubt, or whether one should opt more for an "ethical relativism" that argues for doing what the Romans do when in Rome. Even though one can concede that many traditional ways of thinking and behaving are based on sound assumptions, there are a number of situations where a corporation should have the courage to apply its own standards and philosophy and not that of the different social and cultural framework of the host country.

Sensitive areas might be, for instance, marketing, information policy, environmental protection, animal experiments, research policy, or other areas for other fields. Ethically acceptable maneuverability must be clarified and its effects on people, environment, and society analyzed. In a phase of evaluation and weighing up, the desirable and undesirable must be defined and formulated.

In practice, it happens again and again that types of behavior occur in a corporation, which the corporate codes of conduct in force would forbid. The following is a developed criteria, which can increase the practical effectiveness of internal codes of conduct. 


\section{Criteria for the formulation of corporate codes of conduct}

- The principles of the code must be tailored to the specific corporate culture merely taking over general codes is not enough.

- The code of conduct addresses those activities of the corporation which are particularly sensitive or which concern the greatest vulnerability (legal, sociopolitical, and other).

- Corporate codes of conduct have to be pragmatic, i.e., they must reflect the circumstances of the corporation and should only set standards which can reasonably be expected to be followed.

\section{Criteria for the implementation of corporate codes of conduct}

- Firstly, a communication program must ensure that all persons affected by the code of conduct actually know and understand it. It is not enough merely to distribute it, the content should be explained and someone made available to answer questions.

- There should be at least one person who may be approached in confidence (ombudsperson).

- Employees should certify in writing that they have read, understood, and complied with the code of conduct in their work.

\section{Criteria for the enforcement of corporate codes of conduct}

- Work with codes of conduct only makes sense if the managers concerned are accountable for its objectives.

- Audit committees, ombudspersons, a hot line or other means should ensure that employees could have their concerns taken up by the appropriate office.

- Violations of the code of conduct must be investigated and resolved. The message should be clear and leave employees in no doubt: violation of the code leads to penalties, including dismissal, and that irrespective of whether the violation had positive or detrimental consequences for the corporation.

As not only corporations but also probably all the world's institutions have a tendency to be self-referential, i.e., to live in a rather closed value and interest system, it is important that corporate codes of conduct are based on a broad social consensus. They should therefore not only reflect the philosophy of corporate management, but should, prior to their adoption, be seriously challenged by external, independent review and as far as possible result from a consensus based on dialogue. 
In his discussion of the state (politeia), Plato state a hierarchy of behaviors by means of which "insight into things" can be gained or the way to truth be found. At the top is "understanding", followed by "sense (thought)", "belief (what is thought to be true)", and then mere "supposition". Even today, in many situations it seems valuable and appropriate to draw attention to this hierarchy.

\section{CONCLUSION: A FINAL WORD}

\section{Charitable Giving: A Corporate Responsibility?}

If you're lucky enough to live in a community that is vibrant and active, you're sure to be tapped to participate on a committee, sponsor an event, or contribute in some way to a non-profit organization. But how can you be a good corporate citizen without draining your resources? And, more importantly, why should you contribute?

Whether you're a one-person operation or have one million employees across three continents, you might want to pay attention to what your involvement-or lack thereof-says about you. Quite simply, to participate in your community is good business. It creates a good impression, and it's been known to bring in new business.

Now, let's take care of the nay (no) sayers. Some businesses claim that if they give to one, they would feel obligated to open the door to others. Others say they get calls everyday from someone asking for a donation, so they use the "Just Say No" philosophy.

But you don't have to break the bank to help out groups that ask for some kind of assistance. And there is no obligation to help out everyone who calls; you got to choose.

You can make it easy on yourself by considering some charitable giving in your yearly budget. (the company's marketing plan included the community relations component or donations). If you're particularly fond of a specific non-profit organization or community event you feel is worthwhile, you can target your donations in that direction. The corporation might also consider stretching out its contributions among several worthy causes, and you can vary these from year to year. That way, your community involvement is more widespread, and new groups or events have a chance at getting some funding.

Groups or organizations that rely on donations report that more and more donors are asking for recognition. So, in this day of the shrinking charitable rupees, organizations are becoming more creative in acknowledging donors. For the business owner, this could be a form of what I call "back door advertising". If you can't give rupees, you should consider other ways to help. These are often called "services in kind":

- $\quad$ Serve on a committee for a community event.

- Accept a board position for a local non-profit organization when asked. 
- Encourage your employees to become involved in community organizations or special community events (and pay them for the time they're away from the job, if possible).

- Offer to run off event flyers (printed notice, handbill, etc.) on your copier. (You don't have to run off 5,000, but if you do 500 and other businesses run off 500, no one gets hit too hard.)

- Offer to make some phone calls to other businesses asking for donations or services in kind.

- $\quad$ Set aside a place in your store or window for community events flyers.

- $\quad$ Offer to distribute flyers to other businesses on your street.

- Shift the focus of your regular advertising by offering to place an ad about the event with your local media. For example: "ABC Company is proud to welcome Art Council's Annual Fireworks on February 5." You've killed two birds with one stone: you've gotten good exposure for your business, and you've connected it to a positive experience.

Just as in rupee donations, recipients of in-kind services should also acknowledge such contributions because, for a businessperson, time or resources translate into rupees.

Your business community also needs you to make decisions on issues that impact your neighborhood, your community and the economic climate. The fastest way to effect changes within a system is to get into a leadership position within it.

So, the next time upon receiving a call asking for donations, consider these scripts: 1) "I'm sorry, but I've already committed to a number of community events this year, but if you'll send me a letter with your request, I'll give it consideration next year."

2) "Sorry I can't give you money this year, but can I help another way?"

3) "I've budgeted some money for donation this year. Tell me more about your group."

\section{NOTES \& REFERENCES}

See Business Week of May 29, 1989, p. 29. According to a representative survey conducted by the Institute for Applied Marketing Science in the German Federal Republic in 1989, the large chemical companies seem to come in for particularly heavy criticism: one of the questions was "Which company is especially irresponsible, immoral, unethical?" $18.8 \%$ of those questioned named BASF, $18.2 \%$ Bayer, and $12.6 \%$ Hoechst. Nevertheless, there were some positive indications: $5.2 \%$ considered BASF "particularly exemplary"; Bayer achieved 2.4\% and Hoechst 1.9\% here. 
T M Gautschi F H: Will the Ethics of Business Change? A Survey of Future Executives, Journal of Business Ethics, Vol. 7 (1988), p. 231.

Brenner S N Molander E Al. Is the Ethics of Business Changing?, Harvard Business Review, Jan/Feb 1977, pp. 57-71.

See for example, Vitell and Festervand 1987: Business Ethics: Conflicts, Practices and Beliefs of Industrial Executives, Journal of Business Ethics, Vol 6, (1987), pp. 111-122.

Goodpaster K E. Ethics in Management, Harvard Business School, Boston 1984, p. 6.

With all the differences in value systems, at least a minimal consensus about commonly accepted values is necessary, otherwise a dialogue can achieve no constructive results. Fundamentalist positions of "never" and "no way" can never lead to compromises.

Concept and Cases in Business Ethics. Prentice Hall, 2001.

George A Steiner and John F. Estiner. Business, Government and Society, A Managerial Perspective, 7th Edition, McGraw-Hill, International Edition.

Social Responsibility means:

"The businessman's decisions and actions taken for reasons at least partially beyond the firms direct economic or technical interest."

Keith-Davis. "Can Business Afford to ignore Social Responsibilities?”, California Management Review, Spring 1960. 